\title{
Species Diversity and Food-web Complexity in the Caves of Malaysia
}

Study Area: Malaysia

Coordinates: $2^{\circ} 30^{\prime} \mathrm{N} 112^{\circ} 30^{\prime} \mathrm{E}$

Key words: Cave fauna, Malaysia, invertebrates, bats, food-web

Besides microbes a wide variety of cave animals inhabit various caves of Malaysia, ranging from tiny invertebrates through to small mammals, reptiles, amphibians and bats. Evidence even supports the visitation of elephants to some caves. In the present report the food web complexity and the species diversity that exist in Malaysian caves is described on the basis of direct sightings. Furthermore, the major threats to the present status of such caves arealso discussed.

\section{Introduction:}

Malaysia is located in southeast Asia and is divided into two distinct parts. Peninsular Malaysia is situated south of Thailand, north of Singapore and east of the Indonesian island of Sumatra. East Malaysia is located on the island of Borneo, and shares borders with Brunei and Indonesia. The two states in east Malaysia are Sabah and Sarawak. Malaysia has a tropical climate with a high rainfall and humidity. Over the millennia, large caves have been formed. Many of the caves are located in tower karst hills, there are few limestone ranges. These hills rise steeply from the plains and are isolated from each other, resulting in a high degree of endemism in their fauna and flora. The caves in Peninsular Malaysia are of moderate size, usually not exceeding $4 \mathrm{~km}$ in length, whereas the longest cave in east Malaysia is over $200 \mathrm{~km}$ this is Clearwater Cave in Mulu National Park in Sarawak.

Many caves have large chambers and passages with multiple entrances or big high level openings. The majority of them are dry although some still have active stream passages. Some caves are seemingly devoid of fauna, whereas others have thriving communities, , (Price, 2004).

\section{Bats: the major sources of energy input inside the cave:}

In many temperate caves, especially in Europe, it can be quite diff icult to see cave fauna except in the entrance zones (Vandel, 1965; Gunn, 2004; White and Culver, 2012). Tropical caves are usually much more densely populated by fauna and some contain huge colonies of bats (Hall, 1994, 1996; Meredith et al., 1992; Biswas, 2010; Biswas et al., 2011). Bats, and to lesser extent cave swiftlets, can substantially 
support the food chain for any cave. They feed outside of the caves, when they return to the cave they deposit large volumes of guano on the cave floor. Their faeces and urine provides the main basis for the entire food web in many caves. The cave food web can be quite complex but is primarily based on the guano. There are two main types of bats that inhabit Malaysian caves, the insect eaters (insectivores) and fruit eaters (frugivores), (Price, 2004; Abdullah et al., 2007). When they return to the cave after feeding, their resulting guano indirectly serves as food sources for most of the cave fauna, from the smallest invertebrates that feed on the guano, which in turn are food to the larger cave dwelling snakes, amphibians and small mammals.

Bats are usually beneficial to humans. The insect eating bats are a form of natural insect pest controller, whereas the fruit bats are important pollinators of some tropical fruit crops, especially those which flower at night. In Deer Cave, Mulu National Park of Malaysia; it is estimated that between 1-2 million bats inhabit the cave, (Hall, 1996). Each night they emerge from the cave to feed, and if each bat eats around $10 \mathrm{~g}$ of insects, this represents $10,000 \mathrm{~kg}$ of insects consumed during a single night. Fortunately in Malaysia, cave bats are usually not disturbed by humans, whereas in other countries in Southeast Asia, bats are even caught by humans for food purposes (Price, 2007b).

Over the decades guano has been removed from some caves for use as fertiliser. Some large guano deposits appear to be physically moving due to the large numbers of invertebrates crawling in and on the guano as they go about their daily lives. This phenomenon is particularly noticeable in caves such as Dark Cave in Peninsular Malaysia and Gomantong in Sabah (east Malaysia). Both these caves are open to tourists and support large colonies of cockroaches in their threshold zones (Fig.-1).The huge accumulation of guano in Gomantong cave has already featured in a few natural history based documentaries, (Fig.-2).

Besides food, guano also provides the habitat for many invertebrate populations in Malaysian caves, including ants (Hymenoptera), harvestmen/daddy long legs (Opiliones), true fly larvae (Diptera), beetles (Coleoptera), true bugs (Hemiptera), springtails (Collembola), millipedes (Diplopoda), woodlice (Isopoda), worms (Oligochaeta), mites (Acaria) and moths (Lepidoptera).

\section{The dynamics of predator-prey relationships inside the caves :}

Many of the organisms mentioned in previous section have been seen to be preyed upon by cave crickets (Orthoptera), centipedes (Chilopoda, including long legged centipedes (Scutigeromorpha)), cockroaches (Dictyoptera), scorpions (Scorpionida), spiders (Araneae), whip scorpions (Uropygi) and whip spiders (Amblypygi) in Malaysian caves (Fig.-3 \& 4).

These invertebrates provide food for small mammals, frogs, toads (Fig.-5), terrapins (Fig.-6), geckoes and many aquatic organisms including fish and crabs, where free water exists. Larger mammals such as rats and porcupine are also found to live in Malaysian caves (Fig.-7). Wild boar bones and carcass have also been seen inside a few caves in Malaysia. Even elephants visit some caves, as can be seen by rub marks on the walls, large deposits of droppings and the skeleton of a young elephant that was found in a cave entrance in Pahang (Fig.-8).It is still unknown why the elephants visit such caves. At the Kitum Caves in Kenya, elephants go into the caves to eat minerals from the rocks, but the same phenomenon is not thought to be the case for Malaysian caves, (Lundberg \& McFarlane, 2006). In some caves in Pahang, tiger footprints have also been seen in cave entrances.

Birds such as the bat hawk (Macheiramphus alcinus) hunt on bats and cave swiftlets as they fly in and out of the caves in Malaysia. Rock thrushes (Myophonus spp.) normally feed on insects, seeds, fruit and small reptiles and rodents, but have been observed to chase and catch bats (Khoo, 2012). It is well known that many spiders use webs to ensnare prey but this technique is also used by some diptera 


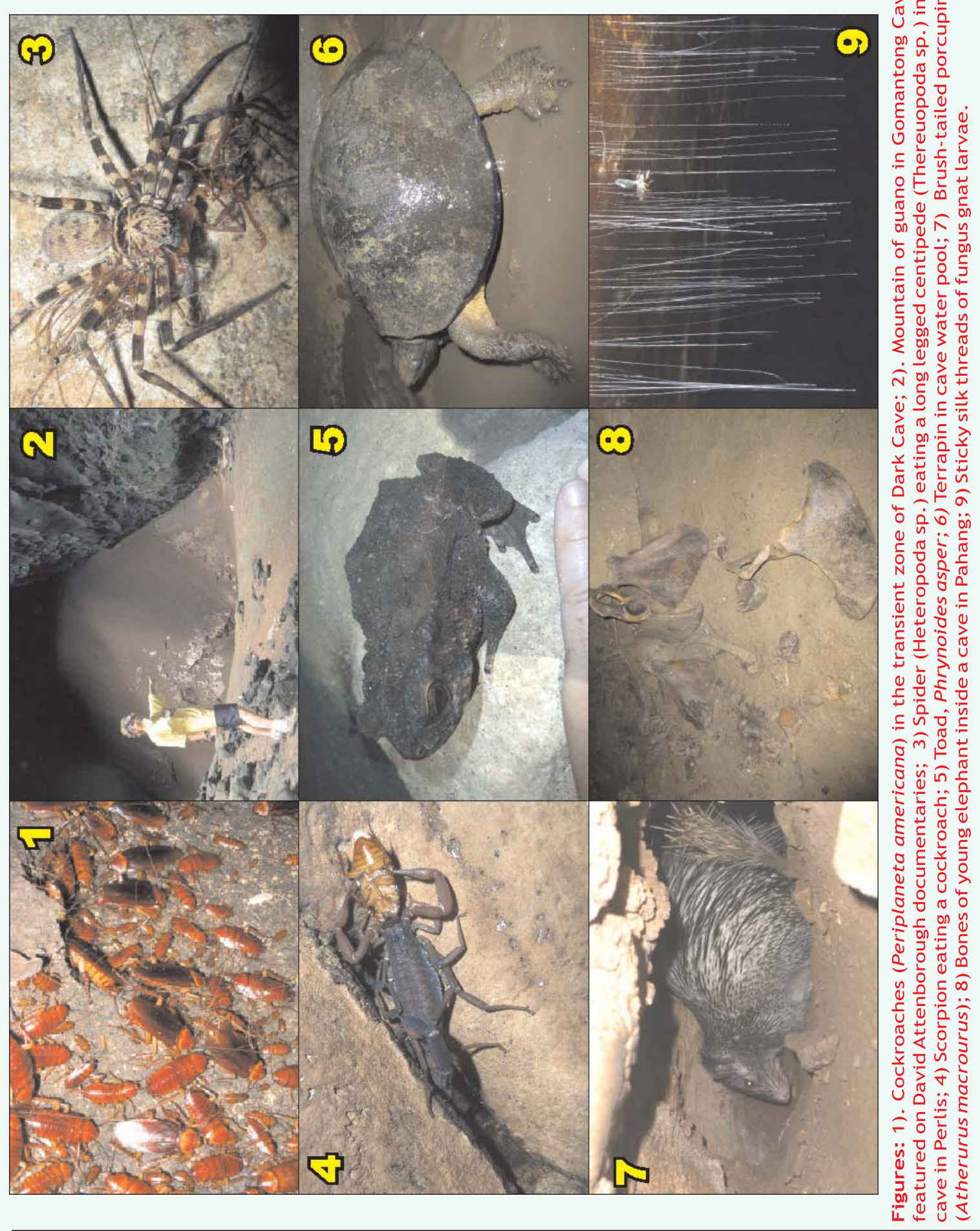

Ambient Science (2014)

http://www.caves.res.in/

Vol.-1(2): p- 03 
(true flies) including fungus gnat larvae in Malaysian caves. These worm-like larvae hang sticky silk threads to ensnare prey. The larvae spin a silken nest on the ceiling then hang down as many as 70 threads (called snares) from the nest. These snares hold droplets of mucus which entrap any prey (Fig. 9).

Animal carcasses, especially those of bats and swiftlets, are scavenged very quickly, and the bare skeletons are rapidly exposed (Fig. 10, 11). Bats and cave swiftlets support a range of parasites that make a unique contribution to biodiversity and include a range of mites, ticks, fleas and bat flies. Particularly noticeable in Deer Cave are hairy earwigs, Arixeniaesau, (Dermaptera: Arixeniidae) that live on the naked bat (Cheiromeles torquatus), feeding on oils produced by the bats to protect their skin (Price, 2004).

At the top of many Malaysian caves' food chains are snakes. In Malaysian caves, the cave racer, Orthriophis taeniurus, (Squamata: Colubridae) is the only known snake that can spend its whole life within caves, feeding exclusively on bats and swiftlets, (Price \& Ya-Wei, 2007) (Fig. 12). The cave racer occurs outside caves as well, though is rarely seen. The cave racer can climb walls to reach its prey, where it rests with its head hanging out waiting to ambush its prey as they fly past. The snake is then seen to constrict its victim before swallowing it (Price, 1998). Several other types of snakes are occasionally found in caves, such as pythons and rat snakes but these have to be considered as accidental visitors (trogloxenes) which never complete their life cycle in caves.

\section{Earlier reports:}

Studies on the cave fauna in Malaysia began in earnest at the end of the 19th century. The cave racer snake was the first reported species by Ridley (1898), whilst at the same time other scientists embarked on extensive faunal studies on the Malay peninsula; including what is now south Thailand, (Annandale 1900, Annandale et al., 1913).The first comprehensive study on invertebrates from the Dark Cave (Batu Caves) published by Dover in 1929.

It could be suggested that the fauna in these tropical caves is not especially adapted to hypogean habitats. Many taxa recorded from these caves are associated with guano deposits and among them the majority of the taxa can also be found in epigean habitats (Annandale et al., 1913). Very few species have adapted themselves to living in a totally dark environment and developed troglomorphisms in Malaysian caves. The most notable is a white and eyeless cave crab from Mulu (Ng \& Shaharin, 1990).

Many insect cavernicoles have elongated legs, as well as very long antennae to both navigate and to locate their prey. The legs and antennae can be several times longer than the body, especially in the case of long legged centipedes (Thereuopoda longicornis; Scutigeromorpha) (Fig. 13), cave crickets (Orthoptera) (Fig. 14) and the whip spiders (Amblypygi) (Fig. 15).

Many of the cavernicoles recorded in Malaysia were found to be endemic to a single cave, hill or region. These include land snails and trapdoor spiders (Liphistius spp.). From eight land snail genera examined by Davison (1991), 78 species were found to be site endemics (species restricted to single isolated area of karst) in Peninsular Malaysia. The trapdoor spider, Liphistius batuensis, has only been recorded from Dark Cave at Batu Cave and the nearby Gua Anak Takun. Liphistius kanthan is endemic to Gua Kanthan in Perak (Fig. 16) and is now on the IUCN Red List as Critically Endangered, but its existence is threatened as the hill is being quarried, (Whitten et al., 2013). Liphistius tempurung is known from Gua Tempurung (Platnick et al, 1997) and one more nearby cave, Gua Cicak in Perak (unpublished). Few species may have been misidentified in the past, such as the Australian Cockroach, Periplaneta australasiae from Dark Cave at Batu Caves (Price \& Steiner, 1999). 


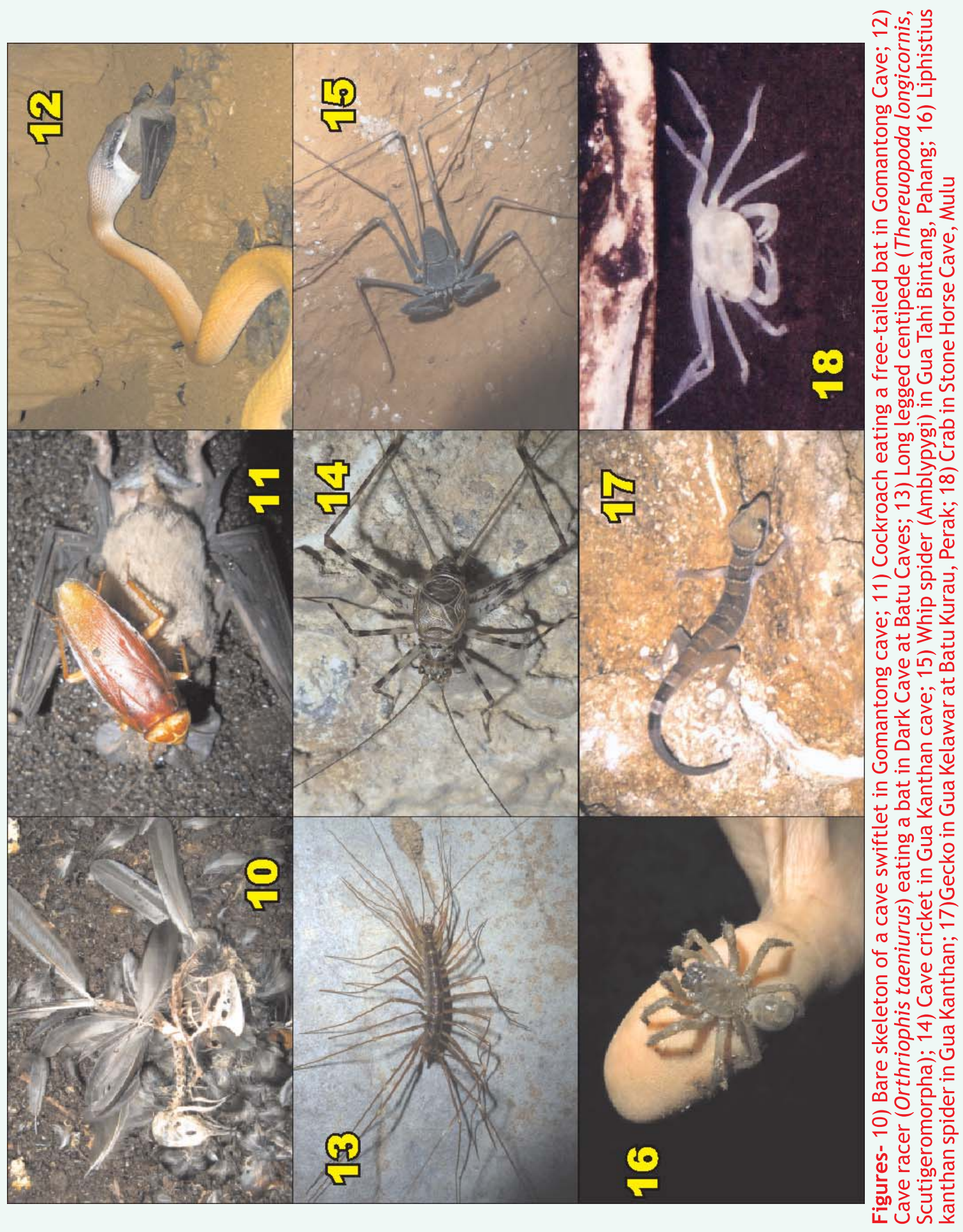

Ambient Science (2014)

http://www.caves.res.in/

Vol.-1(2): p- 05 


\section{Conservation status of the Malaysian caves:}

Some cave communities are under threat of invasion by epigean fauna, for example, the cave cockroach, Pycnoscelus striatus, (Blattaria: Blattidae) at Batu Caves seems to be less numerous than in the past,while the epigean or domestic forms of cockroach (Periplaneta spp.) appear to be increasing (Price \& Steiner, 1999). This particular threat may be relatively localised to some Malaysian caves due to the fact that some of the caves have been utilised for tourism, as temples or as temporary dwellings by nest collectors.

As relatively few cave faunal studies have been undertaken in Malaysian caves, new species can still be discovered. For example, a few new species of geckoes inhabiting caves and limestone hills have been described (Grismer \& Onn 2009; Grismer et al., 2008a,b; Grismer et al., 2009; Grismer et al., 2013; Grismer et al., 2014a,b) (Fig. 17) .Unfortunately, two of these sites are in danger of being quarried (Grismer et al.,2013, Grismer et al., 2014a; Price, 2013a,b,d,e).

The fine balance of tropical cave ecosystems is being upset in a variety of ways. Anthropogenic activities include the collection of guano for use as a fertiliser. This practice has been undertaken for over a hundred years, and archaeological remains have been lost through its indiscriminate collection. In some caves, pits over 2-3m deep show that guano has been removed. In addition, in east Malaysia, cave swiftlet nests have been harvested over the centuries for birds nest soup. The edible nests command a high price; $1 \mathrm{~kg}$ of processed white cave nest can fetch around US \$50oo. In the past, nests were collected all year round, resulting in a severe depletion of swiftlet numbers. Now in some caves, the activity is regulated and harvesting is restricted to two or three times a year, to allow the bird populations to recover; although the removal of the nests at any time results in the death of baby birds and this may ultimately lead to the decline of the species. However in Malaysia there is now a huge increase in swiftlet farms. These purpose built 'bird hotels' are found in many places, both rural and urban, and will hopefully take the pressure off the cave swiftlets.

Although many tropical caves are rich in cave fauna, there appears to be a decline in the numbers of some groups of its inhabitants, particularly bats (Kock et al., 2000; Harries et al., 2008; Biswas et al., 2011). This is probably because of increasing development and industrialization in areas around the caves and as a result, the bats have further to travel to obtain food. When combined with a reduction in food due to the widespread use of insecticides and other chemical pollution, and a reduction in habitat due to quarrying activities, the threats to bat populations are considerable (Kock et al., 200o; Biswas, 2009; Whitten, 2013). Quarrying of limestone hills in Malaysia is a major concern. In the ever increasing demand for cement and stone products, more and more limestone hills are being leased to quarry companies and few hills have any protection.

\section{Conclusion:}

Tropical caves are fragile and vulnerable habitats. They support a diverse range of fauna, many of which are dependent on the protection the cave habitat affords them and of the bat and/or swiftlets that provide the energy to drive the food chain. Comparatively few detailed faunal studies have been undertaken in Malaysian caves in recent decades and there is an urgent need for future research to carefully document the cave associated flora and fauna so that appropriate management and conservation measures can be implemented to protect them for future generations.

\section{References:}

Abdullah M.T.; Hall, L.S.; Tissen O.B.; Tuuga A.; Sulaiman S. \& Earl of Cranbrook (2007): The large bat caves of Malaysian Borneo. Bat Research News, 48:99-100. 
Annandale, N. (1900): Notes on Orthoptera in the Siamese Malay states. The Entomologist's Record and Journal of Variation, Jan-Dec, XII, p75-77, 95-97.

Annandale N., Coggin B.J. \& Gravely F.H. (1913): The limestone caves of Burma and the Malay Peninsula.Journal of the Asiatic Society of Bengal, 9(10);391-423.

Biswas J. (2009): The biodiversity of Krem Mawkhyrdop of Meghalaya, India, on the verge of extinction. Current Science, 96(7), 904-910.

Biswas J. (2010): Kotumsar Cave biodiversity: a review of cavernicoles and their troglobiotic traits. Biodivers. Conserv, 19(1);275-289.

Biswas J., Shrotriya S., Rajput Y. \& Sasmal S. (2011): Impacts of Ecotourism on Bat Habitats in Caves of Kanger Valley National Park, India. Res. J. Environ. Sci... 5(9):752-762.

Bullock J.A. (1971): Fauna of Gua Anak Takun. - Malayan Nature Journal, 24:95-97.

Davison G.W.H. (1991): Terrestrial molluscs of Peninsular. In: Kiew R, (ed.) The State of Nature Conservation Kuala Lumpur (Malaysia): Malayan Nature Society. pp. 101-104

Dover C. (1929): The fauna of Batu Caves.Journal.Federated Malay States Museum., 14:325-387.

Doyle M.E. (1969): Factors affecting distribution of fauna in Gua Pondok. - Malayan Nature Journal,23:21-26.

Grismer L.L. \& Onn C.K. (2009): A new species of karst dwelling Cnemaspis Strauch 1887 (Squamata: Gekkonidae) from Sarawak, Borneo. Zootaxa, 2246:2131

Grismer L.L., Onn C.K., Nasir N. \& Sumontha M. (2008a): A new species of karst dwelling gecko (genus Cnemaspis Strauch 1887) from the border region of Thailand and Peninsular Malaysia. Zootaxa, 1875:5168.

Grismer L.L., Grismer J.L., Wood P.L. \& Onn C.K. (2008b): The distribution, taxonomy, and redescription of the geckos Cnemaspis affinis (Stoliczka 1887) and C. flavolineata (Nicholls 1949) with descriptions of a new montane species and two new lowland, karst-dwelling species from Peninsular Malaysia. Zootaxa, 1931:124.

Grismer L.L., NorhayatiI A., Onn C.K., Belabut D., Muin M.A., Wood P.L. \& Grismer J.L. (2009): Two new diminutive species of Cnemaspis Strauch 1887 (Squamata: Gekkonidae) from Peninsular Malaysia. Zootaxa, 2019:4056.

Grismer L.L; Wood P.L; Mohamed M., Onn C.K., Heinz H.M; Sumarli A.S-I, Jacob C.A. \& Loredo A.I. (2013): A new species of karst-adapted Cnemaspis Strauch, 1887 (Squamata: Gekkonidae) from a threatened karst region in Pahang, Peninsular Malaysia. Zootaxa 3746 (3)463472, (3 fig. 2 tab.).

Grismer L. L.; Belabut D.M; Quah E.S.H; Onn, C. K.; Wood, P.L..\& Rosli H. (2014a): A new species of karst forestadapted Bent-toed Gecko (genus Cyrtodactylus Gray, 1827) belonging to the C. sworderi complex from a threatened karst forest in Perak, Peninsular Malaysia.Zootaxa, 3755(5)434-446, (4 fig. 6 tab.).

Grismer L.L., Wood P.L., Onn C.K., Anuar S. \& Muin M.A. (2014b): Cyrts in the city: A new Bent-toed Gecko (Genus Cyrtodactylus) is the only endemic species of vertebrate from Batu Caves, Selangor, Peninsular Malaysia.Zootaxa, 3774 (4):381394, (5 fig. 6 tab.).

Gunn J. (2004): Encyclopedia of karst and caves.Fitzroy Dearborn, Chicago and London, PA.

Hall L.S. (1994):The magic of Mulu. Bats, 12(4)8-12.

Hall L.S. (1996): Observations of bats in GuaPayau (Deer Cave), Gunung Mulu National Park, Sarawak. Sarawak Museum Journal, L(71)111-124.

Harries D.B., Ware F.J., Fischer C.W., Biswas J. \& Kharpran-Daly B.D. (2008): A review of the biospeleology of Meghalaya, India.J Cave KarstStud, 70 (3), 163-176.

Khoo S.Y. (2012): Field study. Meat-eating chats: more observations on Blue Whistling Thrushes Myophonus caeruleus in Peninsular Malaysia. Birding ASIA, (Oriental Bird Club), 17:6064, (10 pl.).

Kock D., Altmann J. \& Price L. (2000): A fruit bat new to West Malaysia: Rousettus leschenaultia (Desmarest 1820) in Batu Caves. Malaysian Nature Journal, 54(1)63-67. 
Lundberg J. \& McFarlane D.A. (2006): Speleogenesis of the Mt. Elgon 'Elephant' Caves, Kenya. In: Harmon, R.S. and Wicks, C. (Eds) 'Perspectives on Karst Geomorphology, Hydrology, and Geochemistry A Tribute Volume to Derek C. Ford \& William B. White'. Geological Society of America Special Paper 404, p. 51-63.

McClure H.E., Lim B.L. \& Winn S.E. (1967): The Fauna of the Dark Cave, Batu Caves, Kuala Lumpur, Malaysia. Pacific Insects, 9:399-428.

Meredith M; Wooldridge J, \& Lyon B. (1992): Giant Caves of Borneo. Tropical Press (Kuala Lumpur). 142 p.

Ng P. K.L. \& Shaharin Y. (1990): The cave crabs of Bidi, Sarawak. NM 15(3) 74-79.

Platnick N., Schwendinger, P. \& Steiner, H. (1997): Three new species of the spider genus Liphistius (Araneae, Mesothelae) from Malaysia. American Museum Novitates, 3209, 13p.

Price L.(1998): Cave fauna. The cave racer.International Caver, 22:16-18.

Price L.(2004): An introduction to some cave fauna of Malaysia and Thailand. ActaCarsologica, 33(1)311-317.

Price L. (2007a): Gomantong bat caves awash in guano. The Brunei Times, Dec 2 (2 photos).

Price L. (2007b): Lao bush meat. Malaysian Naturalist, 6-4, p25-29.

Price L. (2013a): Liphistius Kanthan needs to be saved. Ipoh Echo, 16-31, 170:7, (photos).

Price L. (2013b): Quarrying: Gua Kanthan spider endangered. New Straits Times, letters, 4 July.

Price L. (2013c): Observations on cave racers, Orthriophis taeniurus (COPE) in South East Asia. In SCHULZ, K-D, p343-352 (photos).

Price, L. (2013d): Save endangered Gua Kanthan trapdoor spider. Star, letters, 4th July.

Price, L. (2013e): Save the Kanthan spider now. The Sun daily, letters, 4 July.

Price L \& Ya-Wei L (2007): The cave racer, Orthriophis taeniurus. Cave E Karst Science, 34(3)129-134.

Price L \& Steiner H (1999): Periplaneta australasia (Blattidae), a new record for Dark Cave, Batu Caves. Malaysian Nature Journal, 53(4)341-344, (1 plate).

Ridley H.N. (1898):The white snake of the Selangor caves. Journal Straits Branch Royal Asiatic Society, 31:99-101.

Schulz K-D. (ed) (2013): Old world ratsnakes. A collection of papers. Bushmaster Publications (Berg, SG), 432pp.

Vandel A.(1965):.Biospeleology: the biology of cavernicolous animals. Pergamon Press, Oxford, PA.

White W.B. \& Culver D (2012): Encyclopedia of Caves (2nd Ed.). Academic Press, USA, 945 p.

Whitten T. (2013): Blink and you'll miss it: how species are being lost before they're even found. The Ecologist (http://www.enn.com/wildlife/article/45645)

Whitten T., Clements R. \& Price L. (2013): Liphistius kanthan. In: IUCN 2013. IUCN Red List of Threatened Species. Version 2013:2. 